\title{
Penerapan Metode Think Pair Share untuk Meningkatkan Keterampilan Menulis Iklan Baris Pada Siswa Kelas IX SMPN 1 Kalidawir
}

\author{
Juminah $^{1}$ \\ ${ }^{1}$ SMPN 1 Kalidawir, Tulungagung \\ Email: ${ }^{1}$ juminah@gmail.com
}

\begin{tabular}{l} 
Tersedia Online di \\
\hline http://www.jurnal.unublitar.ac.id/ \\
index.php/briliant \\
\hline \\
\hline Sejarah Artikel \\
\hline Diterima pada 29 Januari 2018 \\
Disetuji pada 30 Januari 2018 \\
Dipublikasikan pada 13 Februari \\
2018 Hal. 42-50
\end{tabular}

Kata Kunci:

think pair share, keterampilan menulis, iklan baris,

\section{DOI:}

http://dx.doi.org/10.28926/briliant .v3i1.134

\begin{abstract}
Abstrak: Dalam rangka meningkatkan Ketrampilan Menulis Bahasa Indonesia yang memuat Menulis Iklan Baris pada Siswa Kelas IX A SMP Negeri 1 Kalidawir Tulungagung, Peneliti melakukan penelitian tindakan kelas dengan menerapkan pendekatan Think Pair Share pada pembelajaran Bahasa Indonesia. Sasaran penelitian ini adalah siswa Kelas IX A SMP Negeri 1 Kalidawir Tulungagung yang berjumlah 30 siswa. Berdasarkan hasil observasi yang dilakukan di Kelas IX A pada waktu pembelajaran Bahasa Indonesia diperoleh hasil bahwa Ketrampilan Menulis siswa kurang memuaskan, yaitu dari 30 siswa hanya 10 siswa yang nilainya dapat mencapai $\mathrm{KKM}$ atau $\geq 70$, sedangkan 20 siswa lainnya masih belum dapat mencapai KKM atau $\leq 69$. Simpulan dari penelitian ini adalah pendekatan Think Pair Share dapat meningkatkan Ketrampilan Menulis siswa pada pembelajaran Bahasa Indonesia yang memuat Menulis Iklan Baris.
\end{abstract}

Pelajaran Bahasa Indonesia terdapat kompetensi dasar menulis iklan baris dengan bahasa yang singkat, padat, dan jelas. Tujuan pembelajaran tersebut adalah siswa dapat mendaftar butir-butir yang akan dituliskan dalam iklan baris di surat kabar dan dapat menulis iklan baris dengan Bahasa yang hemat. Indikator keberhasilannya yang diharapkan adalah (1) Mampu menentukan objek yang akan diiklankan; (2) Mampu menyingkat kata-kata sesuai dengan kebiasaan iklan baris; (3) Mampu menulis iklanbaris denganbahasa yang singkat, padat, dan jelas; (4) Mampu menyunting iklan baris.

Dari informasi yang di peroleh dari guru Bahasa Indonesia di SMP Negeri 1 Kalidawir Tulungagung, pembelajaran Bahasa Indonesia yang selama ini sudah dilaksanakan di SMP Negeri 1 Kalidawir Tulungagung menggunakan Metode ceramah yang terkadang diselingi dengan diskusi kelompok (pembelajaran kooperatif) dan masih menerapkan keaktifan guru dalam kegiatan pembelajarannya. Pembelajaran cenderung bersifat informatif sehingga keterlibatan siswa secara aktif dalam proses pembelajaran masih kurang. Kondisi yang demikian akan membuat siswa kurang termotivasi untuk belajar. Hal ini terbukti dengan perilaku siswa yang kurang bersemangat dalam mengikuti kegiatan belajar di kelas sehingga nilai siswa pada mata pelajaran Bahasa Indonesia kurang memuaskan. Agar tujuan pembelajaran Bahasa Indonesia di 
SMP dapat dicapai maka perlu adanya inovasi dalam proses pembelajaran Bahasa Indonesia di kelas. Inovasi tersebut dapat berupa model pembelajaran yang bisa membuat siswa menjadilebih aktif dan bersemangat dalam melakukan proses pembelajaran.

Dalam proses pembelajaran di kelas sering timbul masalah yang pada umumnya dialami oleh siswa. Masalah yang dihadapi siswa bersifat unikberbeda satusama lain. Misalnya masalah dan kesulitan ataupun rendahnya Ketrampilan Menulis yang dialami siswa pada mata pelajaran Bahasa Indonesia bisa terjadi karena berbagai faktor diantaranya, keterbatasankemampuan, keadaan, minat dan motivasi diri siswa itu sendiri, situasi belajar di sekolah atau kelas dan kurangnya sarana dan prasarana, materi pelajaran yang kurang relevan dengan kebutuhansiswa dan pendekatan mengajar yang kung bisa dipahami siswa bahkan bahkan kurangnya alat peraga dan alat Bantu mengajar.

Apalagi mata pelajaran Bahasa Indonesia menuntut kemampuan buat siswa mengerti dan memahami tentang materi yang diajarkan dengan tidak hanya rnembaca buku dan teori saja melainkan harus disertai alat peraga,contoh, praktek, latihan soal, seperti soal bercerita dan sebagainya, agar siswa memiliki pengetahuan, keterampilan dan bahkan sikap ilmiah yang berujung pada pemerolehan Keterampilan Menulis yang maksimal.

Berdasarkan hasil pengamatan dalam proses belajar mengajar dikelas, keadaan sekolah, dan melalui peninjauan bidang akademik dan non akademik, diperolehhasil bahwa keadaan Sekolah Menengah Pertama Negeri 1 Kalidawir Tulungagung khususnya siswa Kelas IX A tahun pelajaran 2016/2017 dalam pelajaran Bahasa Indonesia belum menunjukkan Ketrampilan Menulis sesuai dengan KKM yang ditetapkan terutama pada materi pelajaranMenulis Iklan Baris. Padahal, ditinjau dari keadaan fisik sekolah, yaitu ruang Kelas IX A sudah baik dan sesuai sebagai tempat berlangsungnya proses belajar mengajar. Pengamatan pada proses pembelajaran oleh peneliti dapat disimpulkan bahwa pelaksanan proses belajar mengajar lah yang belum membuat siswa aktif belajar, sehingga kemampuan siswa belum tergali denganmaksimal.

Pada ulangan harian Bahasa Indonesia dengan materi Menulis Iklan Baris, di dapat rata-rata nilai sebesar 65,2 dari 30 siswa, padahal Kriteria Ketuntasan Minimalnya (KKM) telah ditentukan nilai sebesar 70. Dan hanya 10 siswa yang mendapat nilai di atas 70 . Hal ini berarti, hanya 33,3\% dari siswa yang telah mencapai ketuntasan belajar, dan yang lainnya memiliki Ketrampilan Menulis yang rendah.

Oleh karena itu, demi memperbaiki berbagai berbagai masalah yang ada, peneliti memerlukan suatu solusi untuk mengatasi hambatan-hambatan yang terjadi, peneliti menggunakan pendekatan Think Pair Sharendalam pembelajaran Bahasa Indonesia ini. Think-Pair-Share adalah pembelajaran dengan cara siswa saling belajar satu sama lain dan mendapatkan jalan keluar dari ide mereka setelah berdiskusi dan membuat ide mereka untuk didiskusikan dalam seluruh kelas (Gunter, 1999).

Menindaklanjuti permasalahan dan solusi yang ditawarkan maka peneliti tertarik utnuk melakukan suatu penelitian guna meningkatkan keterampilan menulis iklan baris dengan menerapkan metode think pair share. Sehingga tujuan penelitian ini adalah untuk mengetahui (1) bagaimana penerapan metode think pair share untuk meningkatkan ketrampilan menulis iklan baris pada siswa kelas 
IX A SMP Negeri 1 Kalidawir Tulungagung, dan (2) apakah metode think pair share dapat meningkatkan ketrampilan menulis iklan baris pada siswa kelas IX A SMP Negeri 1 Kalidawir Tulungagung.

\section{METODE}

Lokasi yang digunakan tempat penelitian adalah ruang Kelas IX A Sekolah Menengah Pertama Negeri 1 Kalidawir Tulungagung Tahun Pelajaran 2016/2017. Dalam penelitian ini subjek yangdigunakan adalah seluruh siswa Kelas IX A Sekolah Menengah Pertama Negeri 1 Kalidawir Tulungagung sebanyak 30 siswa yang terdiri dari 18 siswa putra dan 12 siswa putri.

Metode yang digunakan adalah metode penelitian Tindakan Kelas yang dikembangkan oleh Kemmis dan Mc Taggart (1988) yakni perencanaan (planning), tidakan (acting), observasi (observing) dan refleksi (feflecting). Penelitian ini dilakukan dalam 2 siklus, yang dimulai dari refleksi pada sebelum pelaksanaan perbaikan pembelajaran dimulai. Namun jika setelah siklus ke-II masih belum menunjukkan adanya peningkatan hasil belajar dan pemahaman siswa, maka akandilakukan sampai siklus ke-III. Penelitian ini dilakukan dengan dua siklus, dimana masing-masing diklus dikenai perlakuan yang sejenis dengan bobot yang beda. Dibuat dua siklus dimaksudkan untuk memperbarui system pengajaran yang dilaksanakan.

Pengumpulan data dalam penelitian ini dapat dilakukan dengan menggunakan teknik observasi, angket, dokumentasi, tes, wawancara, dan catatan lapangan.Teknik analisis data yang digunakan dalam penelitian ini adalah teknik analisis data kualitatif yaitu menggambarkan kenyataan atau data sesuai dengan data yang diperoleh dengan tujuan untuk mengetahui peningkatan kualitas kinerja guru. Langkah-langkah analisis terdiri dari tiga alur kegiatan yang terjadi secara bersamaan yaitu : (1) reduksi data, (2) penyajian data, (3) penarikan kesimpulan.

Pada kegiatan reduksi data, peneliti mengumpulkan pelaksanaan pengembangan pembelajaran menggunakan pendekatan Think Pair Share dan Ketrampilan Menulis siswa Data hasil reduksi yaitu pelaksanaan pengembangan pembelajaran menggunakan pendekatan Think Pair Sharepada siklus 1 dan 2, data hasil observasi Guru pada siklus 1 dan siklus 2. Kegiatan penyajian data dilakukan dalam rangka mengorganisasikan hasil reduksi, dengan menyusun secara narasi sekumpulan informasi yang diperoleh dari hasil reduksi hingga memberi kemungkinan adanya penarikan kesimpulan dan pengambilan tindakan.Informasi memberi kemungkinan adanya penarikan kesimpulan dan pengambilan tindakan. Informasi yang dimaksud adalah apakah penerapan pendekatan Think Pair Share dapat meningkatkan Ketrampilan Menulis siswa, pengelolaan Pembelajaran oleh Guru, respon siswa terhadap kegiatan pembelajran, serta hasil yang diperoleh sebagai akibat dari pemberian tindakan. Sajian data selanjutnya ditafsirkan dan dievaluasi untuk merencanakan tindakan selanjutnya.

\section{HASIL}

Pra Siklus

Sebelum melaksanakan proses penelitian, peneliti mengumpulkan data dari informasi tentang subjek penelitian. Data-data yang dikumpulkan antrara lain daftar nama siswa Kelas IX A, daftar nilai ulangan harian Bahasa Indonesia materi Menulis Iklan baris, hasil wawancara dengan informan yaitu siswa Kelas 
IX A SMP Negeri 1 Kalidawir Tulungagung. Dari pengumpulan data, nilai ulangan harian tentang menulis Iklan baris, rata-rata nilai yang didapat hanya sebesar 65,2. Dari 30 siswa, hanya 10 siswa yang mendapat nilai di atas 70 . Ini berarti hanya 33,3\% siswa yang telah mencapai ketuntasan belajar, karena kriteria ketuntasan Minimal (KKM) telah ditentukan sebesar 70.

Daftar frekuensi nilai ulangan Bahasa Indonesia Menulis Iklan baris siswa kelas IX A SMP Negeri 1 Kalidawir Tulungagung pada kondisi awal adalah 2 siswa atau 6,7\% yang mendapat nilai antara $0-40$, ada 18 siswa atau $60.0 \%$ yang mendapat nilai antara 41-69, da nada 10 siswa atau 33,3\% yang mendapat nilai antara 70-100. Dengan ketentuan nilai KKM 70, maka dapat disimpulkan jika pencapaian prestasi nilai 70-100 yang hanya 33,3\% merupakan prestasi yang rendah.

Selain itu, dari proses wawancara diperoleh kesimpulan bahwa siswa kurang berminat dalam melaksanakan kegiatan pembelajaran, serta dalam pembelajaran Guru lebih sering menggunakan ceramah sehingga siswa merasa jenuh dan bosan, akibatnya minat siswa untuk belajar bahasa Indonesia terutama pada Menulis iklan baris menjadi berkurang sehingga mempengaruhi hasil prestasinya.

Berdasarkan hasil data yang dikumpulkan, dapat dikemukakan dua hal pokok yang perlu diatasi, yaitu menumbukan minat siswa untuk belajar Bahasa Indonesia dan memahamkan Menulis Iklan Baris dengan cara mengaktifkan siswa dalam kegiatan belajar mengajar dan meningkatkan Ketrampilan menulis siswa dengan menerapkan pendekatan Think Pair Share pada siklus 1 nanti dengan harapan Ketrampilan Menulis siswa dapat meningkat. Untuk itu perlu dilaksanakan perbaikan pembelajaran pada siklus 1 dan jika belum tuntas maka akan dilanjutkan pada siklus 2 .

\section{Siklus I}

Pelaksanaan siklus I yang dilaksanakan pada hari Rabu tanggal 7 September 2016 di ruang kelas IX A SMP Negeri 1 Kalidawir Tulungagung pada jam pertama dan kedua. Pertemuan direncanakan berlangsung 2x40 menit dilaksanakan pada jadwal terstruktur. Proses belajar mengajar mengacu pada rencana pembelajaran yang telah dipersiapkan.

Langkah peneliti antara lain adalah menyiapkan instrument penelitian, dan bahan ajar salah satunya Rencana Pelaksanaan pembelajaran Siklus I materi pelajaran Bahasa Indonesia Kelas IX A semester 1, dengan Kompetensi dasar 4.1 Menulis iklan baris dengan bahasa yang singkat, padat dan jelas. Serta indikator 4.1.1 Menuliskan objek yang diiklankan dengan, 4.1.2 Menggunakan kata-kata yang sesuai dengan kebiasaan iklan baris. Mempersiapkan pula silabus, materi pelajaran, tugas kelompok atau lembar kegiatan, post test. Peneliti juga menyiapkan evaluasi, evaluasi digunakan peneliti untuk mengukur sejauh mana keberhasilan proses pembelajaran dan lembar angket untuk mengetahui hasil pendekatan pembelajaran.

Kegiatan diawali dengan menjelaskan tentang pendekatan yang akan digunakan yaitu Pendekatan Think Pair Share dan komponen-komponennya kepada siswa. Guru membuka pelajaran dengan mengucapkan salam. Guru memberikan apresiasi kalimat Menulis Iklan Baris, "Anak-anak siapa yang pernah 
membaca iklan pada kolom tersendiri yang terdapat di Koran? Bagaimanakah bentuk iklan tersebut?"

Setelah itu, siswa dibagi ke dalam 6 (enam) kelompok sesuai absensi, setelah itu Guru atau peneliti memberikan penjelasan tentang tujuan pembelajaran dan garis besar Bahasa Indonesia tentang menulis iklan baris.

Setelah itu, siswa bergabung ke dalam kelompoknya masing-masing. Guru atau Peneliti membagi tugas kepada setiap kelompok, untuk menganalisis iklan baris.

Dalam pelaksanaan kegiatan mengerjakan lembar kerja siswa, Guru memberi bimbingan. Secara berkelompok, siswa berdiskusi dalam menyatukan dan menenmukan anggota tubuh dan kegunaannya. Pelasanaan percobaan ini sebagai penerapan awal metode Think pair share digunakan untuk menguji jawaban sementara.

Setelah kegiatan kelompok selesai, dilanjutkan dengan diskusi kelas yang dipandu oleh Guru untuk membahas hal-hal yang idak atau belum terselesaikan dalam kegiatan kelompok. Guru secara bergilir mendekati masing-masing kelompok untuk memberikan penguat serta penjelasan sesuatu hal yang belum dipahami oleh siswa (Kegiatan diskusi adalah kegiatan Metode Think pair share menarik kesimpulan).

Guru atau peneliti membacakan hasil diskusi di depan kelas. Guru berperan sebagai moderator untuk membantu siswa menanggapi hasil presentasi hasil diskusi, atas perintah Guru, kemudian salah satu siswa perwakilan dari masing-masing kelompok melaporkan hasil diskusinya dimuka, siswa yang lain memperhatikan. Guru memberikan ulasan terhadap materi yang belum tersentuh oleh kerja kelompok siswa, serta memberikan ulasan terhadap materi yang belum tersentuh oleh kerja kelompok siswa secara bersama-sama, Guru mengambil simpulan dan mendiskusikannya bersama siswa. Guru memberikan post tes atau quis untuk mengukur keberhasilan yang dicapai siswa. sehingga bisa dilihat peningkatan ketrampilan menulisnya.

Terdapat 11 siswa atau 36,7\% yang mendapat nilai antara 41-69, dan 19 siswa atau 63,30\% yang mendapat nilai antara 70-100. Dengan ketuntasan nilai KKM 70, dapat disimpulkan jika pencapaian presentasi nilai 70-100, maka presentasi belajar siswa telah meningkat dari 33,3\% menjadi 63,3\%. Namun karena belum mencapai target indicator pencapaian siklus I sebesar $85 \%$ atau lebih, maka akan dilanjutkan ke Siklus II.

Selain itu, dari proses wawancara diperoleh kesimpulan bahwa bebrapa siswa menjadi bersemangat dalam belajar bahasa Indonesia, karena pelaksanaan kegiatan belajar Bahasa Indonesia dengan Pendekatan Think pair Share ini dilaksnakan dengan langsung secara mandiri oleh siswa, dan melaksanakan kegiatan bersama kelompok sehingga lebih ringan. Meskipun masih terdapat kendala-kendala seperti yang telah diuraikan dalam laporan observasi

\section{Siklus II}

Berdasarkan hasil refleksipada siklus I, disepakati bahwa siklus kedua perlu dilaksanakan. Pelaksanaan siklus II yang dilaksanakan pada hari Rabu, tanggal 14 September 2016 di SMP Negeri 1 Kalidawir Tulungagung pada jam pertama dan kedua. Pertemuan direncanakan berlangssung $2 \times 40$ menit 
dilaksanakan pada jadwal terstruktur. Proses belajar mengajar mengacu pada bersamaan dengan pelaksanaan belajar mengajar.

Pada siklus 2 ini, Guru lebih memperhatikan dan mendekati siswa dan kelompok yang memerlukan bimbingan, Guru memberi bimbingan bagi siswa dan kelompok yang memerlukan, Guru mengundang memandu siswa dalam melaksanakan percobaan, Karena pada siklus I diketahui masih banyak siswa yang malu untuk maju presentasi dan mengajukan petanyaan, maka pada diskusi baik bertanya maupun menjawab petanyaan.

Langkah peneliti antara lain adalah menyiapkan instrument penelitian, dan bahan ajar salah satunya Rencana Pelaksanaan Pembelajaran Siklus II Mata pelajaran Bahasa Indonesia Kelas IX A semester 1, dengan Kompetensi Dasar 4.1 Menulis iklan baris dengan bahasa yang singkat, padat dan jelas. Serta indikator 4.1.1 Menuliskan objek yang diiklankan dengan ,4.1.2 Menggunakan kata-kata yang sesuai dengan kebiasaan iklan baris. Mempersiapkan pula silabus, materi pelajaran, tugas kelompok atau lembar kegiatan, post test. Peneliti juga menyiapkan evaluasi soal, evaluasi digunakan peneliti untuk mengukur sejauh mana keberhasilan proses pembelajaran. Peneliti pun menyiapkan lembar observasi, untuk mengamati proses pembelajaran dan lembar angket untuk mengetahui hasil pendekatan pembelajaran.

Langkah-langkah yang dilakukan Guru dalam pelaksanaan siklus II ini antara lain, kegiatan diawali dengan Guru membuka pelajaran dengan mengucapkan salam; Guru mengulang materi yang lampau yang berkaitan dengan materi yang akan disampaikan sekarang; Memberikan apersepsi, soal pemanasan untuk siswa seperti Anak-anak Apakah ciri-ciri iklan baris?"

Menjelaskan kembali tentang Metode yang akan digunakan yaitu Metode Think Pair Share dan komponen-komponennya kepada siswa. Siswa menuju kelompoknya masing-masing, setelah itu Guru atau peneliti memberikan penjelasan lagi tentang tujuan pembelajaran dan garis besar Menulis Iklan Baris.

Menjelaskan kembali tentang metode yang akan digunakan yaitu Model Pembelajaran Think Pair Share serta komponen-komponennya kepada siswa. Siswa menuju kelompoknya masing-masing, setelah itu Guru atau peneliti memberikan penjelasan lagi tentang tujuan pembelajaran dan garis besar Menulis Iklan Baris.

Setelah siswa bergabung ke dalam kelompknya masing-masing. Guru membagikan lembar kegiatan yang berisi petunjuk pelaksanaan percobaan untuk penemuan, kemudian menugaskan siswa untuk melaksanakannya. Dalam pelaksanaan kegiatan mengerjakan lembar kerja siswa, Guru memberi bimbingan. Siswa melaksanakan kegiatan percobaan sesuai lembar kegiatan. (1) Dalam satu kelompok terdiri dari 5 orang. (2) Siswa berdiskusi untuk menulis sebuah iklan baris dengan benar. (3) Hasil karya dipajang di dinding kelas. (4) Pelaksanaan percobaan ini sebagai penerapan kedua dan digunakan untuk menguji jawaban kelemahan siklus I).

Setelah kegiatan kelompok selesai, dilanjutkan dengan diskusi kelas yang dipandu oleh Guru untuk membahas hal-hal yang tidak atau belum terselesaikan dalam kegiatan kelompok. Selama siswa berdiskusi, Guru secara bergilir mendekati masing-masing kelompok untuk memberikan penguat serta penjelasan sesuatu hal yang belum dipahami oleh siswa. (Kegiatan diskusi adalah kegiatan Pendekatan Think Pair Share menarik kesimpulan). 
Guru atau peneliti membacakan hasil diskusi di depan kelas. Guru berperan sebagai moderator untuk membantu siswa menanggapi hasil presentasi hasil diskusi. Guru memberikan ulasan terhadap materi yang belum tersentuh oleh kerja kelompok siswa, serta memberikan ulasan terhadap materi yang belum tersentuh oleh kerja kelompok siswa. Sebagai perbaikan siklus I, Guru memberikan reward kepada siswa yang aktif dalam diskusi dan Think Pair Share. Dengan iming-iming reward yang ditawarkan Guru, banyak dari siswa menjadi aktif dalam diskusi dan bertanya ataupun mengungkapkan pendapatnya, bahkan di antara kelompok mereka saling berdebat dengan positif. Secara bersama-sama, Guru mengambil simpulan dan mendiskusikannya bersama siswa. Guru memberikan post tes atau quis untuk mengukur keberhasilan yang dicapai siswa.

Terdapat 2 siswa atau $6,7 \%$ yang mendapat nilai antara $41-69$, dan 28 siswa atau 93,3\% yang mendapat nilai antara $70-100$. Dengan ketentuan nilai KKM 70, dapat disimpulkan jika pencapaian prestasi nilai $70-100$, maka prestasi belajar siswa telah meningkat dari $60 \%$ menjadi 93,3\%. Dengan 93,3\% maka telah tercapai indicator pencapaian siklus II sebesar yang $85 \%$ atau lebih, maka tidak perlu dilanjutkan ke Siklus III.

Selain itu, dari proses wawancara diperoleh kesimpulan bahwa beberapa siswa menjadi bersemangat dalam belajar Bahasa Indonesia, karena pelaksanaan kegiatan belajar Bahasa Indonesia dengan pendekatan Think Pair Share ini dilaksanakan dengan melibatkan masing-masing anggota kelompok, dan didiskusikan bersama kelompok sehingga mereka lebih rileks dan ringan dalam mengerjakan laporan kegiatan. Meskipun masih terdapat kendala-kendala seperti yang telah diuraikan dalam laporan observasi.

\section{PEMBAHASAN}

Berdasarkan hasil pelaksanaan pada siklus I, II dapat dinyatakan bahwa terjadi peningkatan kualitas pembelajaran yang tampak dan perolehan hasil evaluasi dan keaktifan siswa.

Data siklus I hasil observasi menunjukkan, prosentase keberhasilan kelengkapan menyiapkan alat dan bahan percobaan $60 \%$, prosentase keruntutan langkah-langkah yang ditempuh dalam pelaksanaan percobaan $65 \%$, prosentase keaktifan siswa dalam melaksanakan kegiatan percobaan $70 \%$, prosentase keaktifan siswa dalam mengutarakan pendapat saat berdiskusi $68 \%$ dan prosentase hasil penarikan kesimpulan akhir sesuai percobaan $66 \%$.

Data siklus II hasil observasi menunjukkan, prosentase keberhasilan metode kelengkapan menyiapkan alat dan bahan percobaan siswa yang disiapkan $80 \%$, prosentase keruntutan langkah-langkah yang ditempuh dalam pelaksanaan percobaan $90 \%$, prosentase keaktifan siswa dalam melaksanakan kegiatan percobaan $90 \%$, prosentase keaktifan siswa dalam mengutarakan pendapat saat berdiskusi $88 \%$ dan prosentase hasil penarikan kesimpulan akhir sesuai percobaan $87 \%$.

Ketika pelaksanakan siklus I, peneliti mengalami berbagai kendala antara lain masih ada siswa yang kesulitan dalam membedakan antara puisi. Masih ada kelompok yang bingung dalam mengikuti langkah-langkah yang tertera dalam lembar kegiatan.Masih ada beberapa siswa yang belum aktif dalam pelaksanaan percobaan.Ketika pelaksanaan diskusi, ada beberapa siswa yang tidak aktif menyampaikan pendapatnya.Dalam menyimpulkan hasil percobaan, terdapat 4 
(tiga) kelompok yang malu untuk presentasi, dan hanya terdapat 4 (empat) siswa yang mengajukan pertanyaan.

Peneliti kemudian melaksanakan siklus II sebagai perbaikan siklus I, sebelum pelaksanaan siklus II ini peneliti mengganti rencana pembelajaran Model Pembelajaran Metode Think pair share baru yaitu dengan menulis iklan baris untuk kegiatan sekolah. Dalam pelaksanaan percobaan, peneliti senantiasa memberi bimbingan untuk siswanya dalam melaksanakan langkah-langkah sesuai lembar kegiatan.Peneliti pun memberi bimbingan siswa saat berdiskusi untuk menarik kesimpulan.

Dengan adanya motivasi guru berupa reward, siswa telah terlihat aktif dalam kegiatan pembelajaran dalam melaksanakan percobaan, presentasi di depan kelas dan berdiskusi menarik kesimpulan. Meskipun ada kendala yaitu ada beberapa siswa yang masih belum menggunakan kalimat yang baku untuk menulis iklan baris sehingga suasana menjadi gaduh, namun dengan hasil prestasi belajar yang dicapai dapat disimpulkan bahwa penelitian tindakan kelas dari siklus II ini telah berhasil.

\section{KESIMPULAN}

Penerapan pendekatan Think Pair Share dapat meningkatkan ketrampilan menulis iklan baris siswa Kelas IX A SMP Negeri 1 Kalidawir Tulungagung. Hal ini dilihat dari prosentase kenaikan nilai Bahasa Indonesia siswa Kelas IX A dari pra siklus, siklus I sampai Siklus II. Pada pra siklus, siswa yang mendapat nilai minimal 70 ada 10 siswa atau 33,3\%, pada siklus I siswa yang mendapat nilai minimal 70 ada 19 siswa atau 63,3\%, pada siklus II siswa yang mendapat nilai minimal 70 ada 28 siswa atau 93,3\% dari 30 siswa. Dari pra siklus kemudian dilaksanakan siklus I prestasi siswa mengalami prosentase kenaikan 30,0\%. Dan dari siklus I kemudian dilaksanakan siklus II prestasi siswa mengalami prosentase kenaikan $30,0 \%$.

\section{SARAN}

Untuk melaksanakan pengembangan pembelajaran menggunakan pendekatan Think Pair Share memerlukan persiapan yang cukup matang, sehingga guru harus mampu menentukan atau memilih topik yang benar-benar bisa dikembangkan dengan Pengembangan Pembelajaran menggunakan pendekatan Think Pair Share dalam proses belajar mengajar sehingga memperoleh hasil yang optimal. Dalam rangka meningkatkan kualitas kinerja Guru, guru hendaknya lebih sering melatih Guru dengan berbagai pendekatan pengajaran, walau dalam taraf yang sederhana, dimana Guru nantinya dapat menemukan pengetahuan baru, memperoleh konsep dan keterampilan, sehingga Guru berhasil atau mampu memecahkan masalah-masalah yang dihadapi. Perlu adanya penelitian yang lebih lanjut, karena hasil penelitian ini hanya dilakukan di SMP Negeri 1 Kalidawir Tulungagung semester 1 tahun pelajaran 2016/2017, dan untuk penelitian yang serupa hendaknya dilakukan perbaikan-perbaikan agar diperoleh hasil yang lebih baik.

\section{DAFTAR RUJUKAN}

Dimyati \& Mudjiono. 2006. Belajar dan Pembelajaran. Jakarta: Rineka Cipta. Gunter. 1999. Games for Children. London: Oxford University Press 
Kemmis, S. dan Mc. Taggart. 1988. The Action Research Planner. Victoria: Deakin University. 